\title{
The effects of global warming on allergic diseases
}

\author{
Alson WM Chan *, KL Hon, TF Leung, Marco HK Ho, Jaime S Rosa Duque, TH Lee
}

\section{A B S T R A C T}

Global warming is a public health emergency. Substantial scientific evidence indicates an unequivocal rising trend in global surface temperature that has caused higher atmospheric levels of moisture retention leading to more frequent extreme weather conditions, shrinking ice volume, and gradually rising sea levels. The concomitant rise in the prevalence of allergic diseases is closely related to these environmental changes because warm and moist environments favour the proliferation of common allergens such as pollens, dust mites, molds, and fungi. Global warming also stresses ecosystems, further accelerating critical biodiversity loss. Excessive carbon dioxide, together with the warming of seawater, promotes ocean acidification and oxygen depletion. This results in a progressive decline of phytoplankton and fish growth that in turn promotes the formation of larger oceanic dead zones, disrupting the food chain and biodiversity. Poor environmental biodiversity and a reduction in the microbiome spectrum are risk factors for allergic diseases in human populations. While climate change and the existence of an allergy epidemic are closely linked according to robust international research, efforts to mitigate these have encountered strong resistance because of vested economic and political concerns in different countries. International collaboration to establish legally binding regulations should be mandatory for forest protection and energy saving. Lifestyle and behavioural changes should also be advocated at the individual level by focusing on low carbon living; avoiding food wastage; and implementing the 4Rs: reduce, reuse, recycle, and replace principles. These lifestyle measures are entirely consistent with the current recommendations for allergy prevention. Efforts to mitigate climate change, preserve biodiversity, and prevent chronic diseases are interdependent disciplines.

\section{Hong Kong Med J 2018;24:277-84}

\section{DOI: 10.12809/hkmj177046}

${ }^{1}$ AWM Chan *, FHKCPaed, FHKAM (Paediatrics)

${ }^{2}$ KL Hon, MD, FHKAM (Paediatrics)

${ }^{2}$ TF Leung, MD, FHKAM (Paediatrics)

${ }^{3}$ MHK Ho, MD, FHKAM (Paediatrics)

3,4 JS Rosa Duque, MD, PhD

${ }^{1}$ TH Lee, ScD(Cantab), FRCP(UK)

${ }^{1}$ Allergy Centre, Hong Kong Sanatorium \& Hospital, Happy Valley, Hong Kong

${ }^{2}$ Department of Paediatrics, The Chinese University of Hong Kong, Shatin, Hong Kong

${ }^{3}$ Department of Paediatrics and Adolescent Medicine, The University of Hong Kong, Pokfulam, Hong Kong

${ }^{4}$ Division of Rheumatology and Clinical Immunology, Department of Medicine, Queen Mary Hospital, The University of Hong Kong, Pokfulam, Hong Kong

* Corresponding author: awmc@hku.hk

\section{Introduction}

Health hazards that are caused by climate changes are a major public health emergency of the 21st century. The World Health Organization estimates that these will lead to 250000 additional deaths per year by 2030 to $2050 .^{1}$

There is substantial evidence for a rising trend of global surface temperature $\mathrm{e}^{2-7}$ as demonstrated by the progressive elevation in ocean temperature and sea level, ${ }^{8,9}$ the continuous shrinking of polar ice caps, ${ }^{10,11}$ the rapid breakup of the Antarctic ice shelves, the melting glaciers at an increasing rate, ${ }^{12-16}$ and the diminishing snow cover in the Northern Hemisphere at an accelerating pace. ${ }^{17-19}$ The subsequent higher atmospheric levels of moisture retention contribute to more frequent extreme weather conditions including floods, droughts, thunderstorms, typhoons, and heat waves. ${ }^{20-30}$ The rise in the sea level has been considered to be the greatest threat to the world in the near future. ${ }^{31-33}$ If global temperatures continue to increase unabated, sea levels around the world could rise by up to 5 metres in the next century, and may lead to submersion of low-lying lands and even countries, such as the Solomon's Islands, Maldives, Fiji, and Micronesia. Urban metropolises including Hong Kong are even more vulnerable to global warming due to the high population density and essential infrastructures. It has been estimated, for example, that an increase by $1^{\circ} \mathrm{C}$ in the mean daily temperature above $28.2^{\circ} \mathrm{C}$ in Hong Kong has been associated with a $1.8 \%$ higher mortality. ${ }^{25}$ The annual mean temperature has progressively trended upwards by $0.12^{\circ} \mathrm{C}$ per decade from 1885 to 2017 , with a more rapid increase of $0.18^{\circ} \mathrm{C}$ per decade since the $1980 \mathrm{~s}$ (Fig 1). The record-breaking highest temperature was documented on 8 August 2015 with a maximum of $37.9^{\circ} \mathrm{C}$ measured in Happy Valley. ${ }^{26}$ More frequent 


\section{全球暖化對過敏性疾病的影響}

\section{陳偉明、韓錦倫、梁廷勳、何學工、陸俊文、李德康}

全球暖化是一項公共衛生危機。大量科學數據證明全球地面表層溫度 有明顯上升的趨勢, 導致大氣層中的水分增多, 促使極端氣候更加頻 繁、冰量減少和海平面逐漸上升。同時, 過敏病症的患病率上升與這 些環境變化有密切關係, 因溫暖和潮濕的環境有利於常見致敏原如花 粉、塵螨、徽菌和真菌等增長。全球變暖還會加重生態系統的負荷, 進一步令關鍵生物鏈喪失多樣性。二氧化碳過多加上海水變暖, 會促 使海洋酸度增加及減低海水含氧量, 導致浮游生物和魚類生長逐漸下 降, 形成更大的海洋死水區域, 破壞食物鏈和物種多樣性, 而環境 生物多樣性和微生物群譜減少是人類過敏性疾病的風險因素。儘管 國際研究的證據已充分顯示氣候變化與人類過敏病症息息相關, 但 由於各國的經濟既得利益和政治顧慮, 舒緩氣候暖化影響的努力遭 遇強大阻力。國際社會應合力建立一套具法律約束力的強制性措施來 保護林木和節省能源。生活方式和行為的改變也應該在個人層面上提 倡，包括實踐低碳生活、避免食物浪費、實施4R原則（Reduce／減 少、Reuse / 重用、Recycle / 回收、Replace / 替換 ）等。這些生活方 式完全符合目前預防過敏的建議。舒緩氣候暖化、保護物種多樣性和 預防慢性疾病是相互關聯的學問。

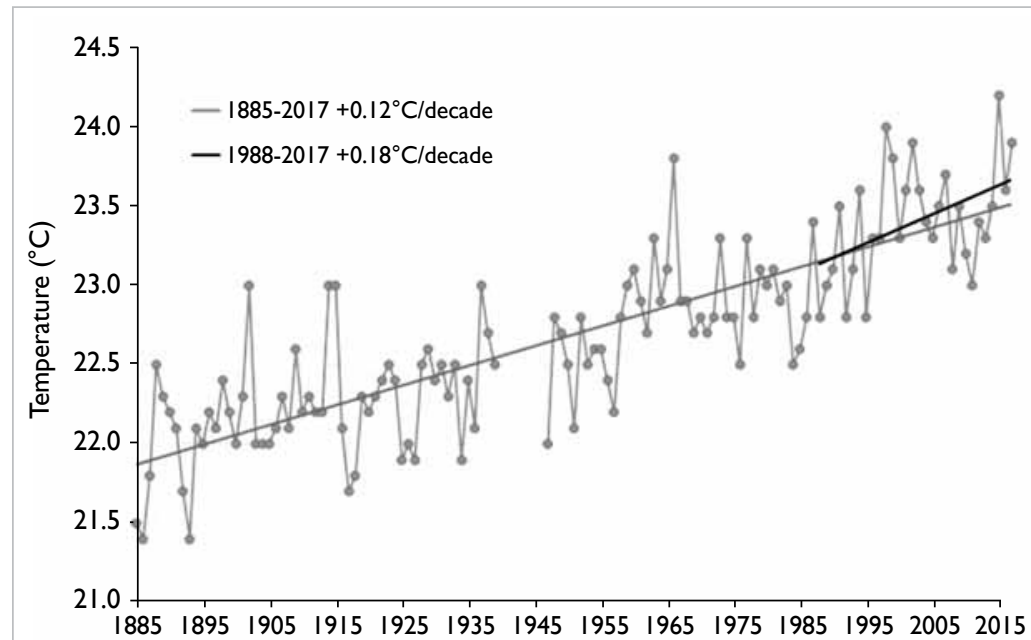

FIG I. Annual mean temperature recorded at the Hong Kong Observatory Headquarters, I885-2017*

* Data not available from 1940 to 1946

Reproduced with permission from the Hong Kong Observatory per decade has been documented since the 1950s. ${ }^{25}$

Climate change will continue to accelerate for the next few decades unless substantial intervening efforts are enforced. It is projected that by the year 2100 , there will be an increase in annual mean temperature by $3^{\circ} \mathrm{C}$ to $6^{\circ} \mathrm{C}$ and there will be significantly greater annual numbers of very hot days (ie, heat waves, defined as daily maximum temperature $\geq 33.0^{\circ} \mathrm{C}$ ) [Fig 2]. Additionally, it is estimated to have a marked increase from 3 to 12 extremely wet years (ie, annual rainfall $>3168 \mathrm{~mm}$ ) during the 21st century. The annual mean sea level is predicted to rise by 0.63 to 1.07 metres, and severe storm surges may become an annual event whilst these have only occurred once every 50 years in the past century. ${ }^{27}$ Nonetheless these projections are likely to underestimate the actual consequences. For example, according to the World Meteorological Organization (WMO), anthropogenic greenhouse gas emissions for 2016 were even higher than those in 2015, increasing from $400.0 \mathrm{ppm}$ to $403.3 \mathrm{ppm}$ in 12 months. Although the rate of this increase appears to have slowed, the warming trend in the climate system will ensure the continued temperature rise long into the future, leading to progressive temperature rises of up to $5^{\circ} \mathrm{C}$ to $6^{\circ} \mathrm{C}$ and with large parts of the Earth potentially uninhabitable in a foreseeable future.

Global warming is a result of human activities. Fossil fuel consumption and industrial processes account for a majority of greenhouse gas production. Moreover, in the past 50 years, urbanisation and intensive agricultural practices have destroyed 50\% of global rainforests. Deforestation, together with excessive fossil fuel combustion during the process of energy production, result in the imbalance and progressive accumulation of anthropogenic greenhouse gases. In addition, carbon dioxide is extremely long-lasting in the atmosphere, with an average half-life of 30 years. Increased methane emissions, many from natural gas production and ruminants raised for food, together with other greenhouse gases such as chlorofluorocarbons used in cooling systems and nitrous oxide compounds emitted from vehicular transport are even more powerful but less long-lasting greenhouse gases. These factors contribute to progressive global warming and extreme weather conditions such as heatwaves, hurricane storms, floods, forest fires, damage to food crops, and growing vectorborne diseases, all of which threaten our living environments and the ecosystem..$^{28-31}$

As the global warming situation has continued to worsen over the past few decades, there has been a concurrent increase in the prevalence of allergic diseases by up to $300 \%$ to $500 \%$ in urban areas. The rate of this increase appears too rapid to be explained entirely by genetics alone, thereby highlighting the important role of environmental changes. ${ }^{32}$ 


\section{Air pollution and allergic diseases}

Epidemiological studies have pointed to a close correlation between global warming, air pollution, and allergic diseases. ${ }^{33}$ The process of industrialisation, increasing vehicle emissions, and a westernised lifestyle are the major contributors to air pollution. Global warming contributes to air pollution by increasing the demands for space cooling, more natural formation of air pollutants (eg, wildfires, soil erosion, decomposition of organic substances such as plants and animals), and enhancing the urban heat island effect that causes the formation of secondary pollutants (such as ozone). Atmospheric pollutants such as nitric dioxide, ozone, and particulate matter are known to be strongly associated with allergic respiratory diseases.

Extreme climatic conditions encourage greater energy utilisation, such as use of heating or air conditioning. This leads to secondary increases in fossil fuel combustion, worsening of air pollutants, and accumulation of tropospheric ozone and particulate matter. Global warming also increases water evaporation and the natural production of pollutants such as desert sand, sea salt, wildfires, and wood heating, promoting the growth of pollens, mould spores and the spread of volcanic ash before they cool down, all of which contribute to the level of particulates in the air. Indoor air pollution consists mainly of a mixture of chemical pollutants and allergens, for example, tobacco smoke, combustion products from heaters and cooking, asbestos, animal allergens, mycotoxins, fungal allergens, cleaning products, painting, adhesive solvents, and furniture chemicals. In particular, tobacco smoke contains at least 3000 compounds, and has five billion particles per cigarette that significantly adds to air pollution especially within indoor environments. Diesel particles adhering to pollens have been shown to be more potent in triggering allergic responses in the airways. Air pollutants affect the lungs and airways directly by attenuating ciliary activity of epithelial cells and increasing permeability of the respiratory epithelium. These effects promote an inflammatory response in the respiratory epithelium and lung parenchyma. ${ }^{34}$

\section{Effect of global warming on common allergens}

Global warming leads to longer pollination seasons and more frequent thunderstorms, sandstorms, and other extreme weather conditions. ${ }^{35}$ Rising temperatures, a higher concentration of carbon dioxide in the atmosphere, heavier rainfalls, and higher humidity induce faster proliferation of pollens, molds, and fungi. This generates atmospheric biological aerosols that carry allergens

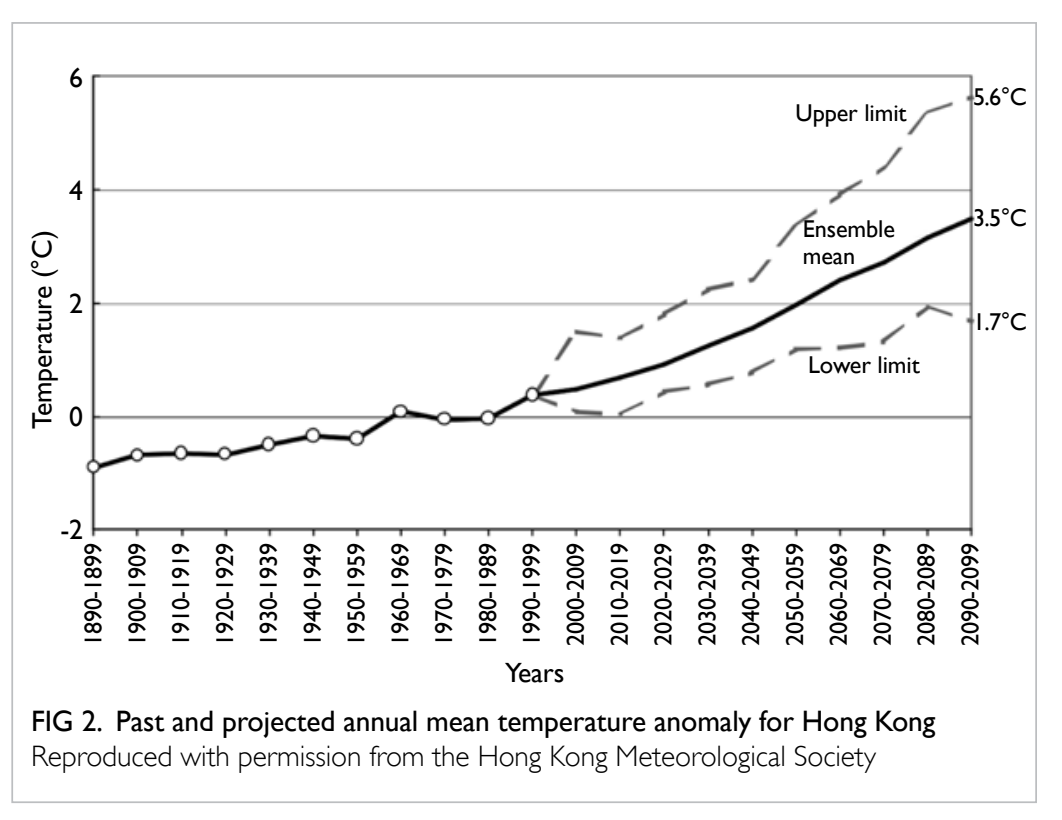

and has caused epidemics of allergic diseases in many countries. ${ }^{36}$

Sandstorms or dust storms are meteorological phenomena that occur more frequently during global warming, at which time small particles of less than $100 \mu \mathrm{m}$ can remain airborne for days floating across hundreds of miles, triggering asthma, pneumonia, allergic rhinoconjunctivitis, cardiovascular and cerebrovascular diseases. ${ }^{37}$

Rising temperatures trigger more heavy rainfalls, frequent storms and the progressive rise in sea levels, causing increased frequency and duration of floods, subsequently exacerbating the surface wearing on buildings. These may induce more rapid growth of molds in our indoor environment. There is a strong and consistent dose-response relationship between home dampness and respiratory symptoms including asthma, suggestive of a causal relationship. ${ }^{38}$ House dust mites and cockroaches prefer warm and humid environments. Sensitisation to house dust mite is more prevalent in temperate and tropical regions of the world, and is associated with allergic rhinitis, allergic conjunctivitis, asthma, and eczema. Nonetheless there are significant differences in specific house dust mite components that trigger allergic diseases between different tropical and temperate areas. ${ }^{39}$ Cockroach allergy is also an important cofactor for both allergic rhinitis, asthma and eczema, with a variable pattern of sensitisation within the same climatic zones. ${ }^{40}$

\section{Effect of global warming on the prevalence of allergic diseases}

Warmer mean temperatures have been shown to be 
associated with a higher prevalence of asthma. In a New Zealand study, a rise in mean temperature of $1^{\circ} \mathrm{C}$ was associated with an increase in asthma prevalence by about $1 \% .{ }^{41}$ In an Italian study that compared two regions with a Mediterranean climate and a subcontinental climate respectively, a higher mean temperature was also associated with an increased prevalence of asthmatic attacks. ${ }^{42}$ In contrast, the International Study of Asthma and Allergies in Childhood (ISAAC) did not find this same correlation between mean outdoor temperatures and the prevalence of asthma. ${ }^{43}$ Nonetheless the ISAAC study was not designed to specifically investigate the effect of temperature change in different subregions.

The more frequent thunderstorm and extreme weather conditions caused by global warming has led to the increased recognition of thunderstorm asthma. Thunderstorm asthma is a separate entity that affects many patients without any history of asthma. It usually occurs during pollen seasons. Epidemics of thunderstorm asthma have been reported in many countries around the world including the US, United Kingdom, Australia, and European countries. ${ }^{44-47}$ The most alarming event was the recent epidemic on 21 November 2016 in Melbourne, Australia that resulted in eight deaths. ${ }^{48}$ In the time series analysis for this epidemic reported in the British Medical Journal, thunderstorm asthma was associated with a $432 \%$ increase in emergency medical attendances for acute respiratory distress symptoms on that evening, an $82 \%$ increase in the incidence of out-of-hospital cardiac arrest and a $41 \%$ increase in prehospital deaths on the same evening of the storm. It is suggested that grass pollens exploded during the thunderstorm, producing pollen fragments that could reach the lower respiratory tract to trigger bronchoconstriction. After the rupture of those pollens by osmotic force, they released allergenic glycoproteins in the form of minute respirable particles which were disseminated up to hundreds of miles. ${ }^{49}$

Asthma-related hospital admissions have been shown to be associated with extreme weather conditions. A recent time series showed an increase in asthma-related hospitalisation during extreme weather conditions such as the high humidity high temperature weather, the low humidity low temperature weather, and during periods of high ozone levels. ${ }^{50}$ Another recent study also revealed that the extent of diurnal temperature difference was positively associated with an increase in hospitalisation due to asthma exacerbation. ${ }^{51}$

Out-patient clinic visits for allergic conjunctivitis were shown to be significantly correlated with higher levels of nitrous oxide, ozone, and higher temperature in a time series conducted in Shanghai, China. ${ }^{52}$ Indoor and outdoor air pollution has been well recognised as a major environmental risk factor for allergic rhinoconjunctivitis. Associated air pollutants include tobacco smoke, products of fossil fuel combustion, dust in Asian region, and phthalates. It is postulated that these air pollutants may be allergenic, irritant, or a combination of both. ${ }^{53-57}$

The prevalence of physician-diagnosed allergic rhinitis has been positively correlated with warmer temperature in studies along the Pacific rim (odds ratio $=1.1,95 \%$ confidence interval $=1.02-1.19) .{ }^{58}$ Studies using ISAAC data showed some regional associations in different age-groups and areas, but this observation was not consistent and has not clearly supported this correlation. ${ }^{59}$

Increased pollen sensitisation has been correlated with global warming according to the US National Health and Nutrition Examination Survey with at least a two-fold rise in the prevalence of sensitisation to perennial rye grass and ragweed during the two periods between 1976-1980 and 19881994. ${ }^{60}$ Similar findings were noted in Canada. ${ }^{61}$

There have been no studies that specifically focused on a link between urticaria and global warming per se, although a few anecdotal reports have observed that during high temperatures associated with global warming patients, tended to wear less clothing, leading to more light exposure that exacerbated their solar urticaria. $^{62}$ As for eczema, there is no known correlation between mean outdoor temperature and its prevalence.

\section{Effect on biodiversity}

The scientific evidence is clear: a rich biodiversity in our living environment is important for human health and prevention of allergic diseases. ${ }^{63}$ Nonetheless global warming and population pressures are disrupting biodiversity in the ecosystem and human living environment. ${ }^{64}$ For instance, the beginning of the plant growing season has already advanced by an average of 10 days in Europe over the last few decades. These changes have altered food chains and created mismatches within ecosystems where different species have evolved synchronised interdependence, such as nesting and food availability, pollinators, and fertilisation. Climate change is also shifting the habitat ranges of disease-carrying organisms, bringing them into contact with potential hosts that have not developed any immunity. Freshwater habitats and wetlands, mangroves, coral reefs, Arctic and alpine ecosystems, dry and subhumid lands, and cloud forests are particularly vulnerable to the impacts of climate change. Many species are not equipped to adapt to the pace and scale of the progressive climate change, resulting in extinction, both locally and globally. In addition, seawater warming and ocean acidification due to excessive carbon dioxide lead to a progressive reduction in the growth of phytoplankton and fish and overgrowth of 
bacteria that depletes the oxygen content of water. These local changes boost the size and extent of oceanic dead zones and influence the food chain and biodiversity well beyond the Arctic. ${ }^{65}$

Urban residents have been found to have significantly more atopy such as asthmatic symptoms, rhinitis, eczema, and higher exhaled nitric oxide values than those who live in a rural environment. ${ }^{66}$ Exposure to the rich microbial diversity and variety of animals within rural areas plays a major protective role against the development of asthma and allergic diseases. ${ }^{67} \mathrm{~A}$ number of risk factors for atopic asthma related to urbanisation have been identified, including decreased family size and sibling numbers, frequent use of antibiotics especially during the infantile period, increases in environmental pollutants and household exposure to indoor allergens, decreased raw and fresh food consumption, sedentary lifestyle, higher socioeconomic status, and reduction in environmental exposure to microbial endotoxins. ${ }^{68}$

Insect migration may be affected by global warming. In a retrospective review of three different patient databases in Alaska, there were statistically significant increases in the prevalence of insect sting reactions accompanying the rise in annual temperatures, suggesting expansion of the insect habitats and redistribution related to global warming. ${ }^{69}$ Invasive insect species such as destroyer ants and European fire ants are expanding their influence on humans due to the increase in quantity and quality of suitable habitats for them related to global warming. ${ }^{70}$

\section{Food supply and food choice}

Global warming leads to more extreme weather conditions such as heavy rainfalls, drought, frequent storms, floods, and heat waves. As aforementioned together with the sea warming effect that also damages the food chain and biodiversity, all of these factors have a detrimental effect on crop harvest and food production. It has been shown that an increase in outdoor temperature is associated with a decreasing trend in the nutrient content and total amount of crop yield per year. ${ }^{71}$ The fall in food production increases the price of fresh and raw foods, and encourages consumption of less expensive and unhealthy food alternatives that contain more artificial colours, chemicals, and preservatives. Recent research has shown that fresh foods with natural ingredients contain a richer diversity of microbiome, now known to be very important for intestinal immune health. On the contrary, prolonged consumption of preserved or refined foods with a poor diversity of microbiome is associated with the development of allergic, inflammatory, cardiovascular, and gastrointestinal diseases. ${ }^{71}$

\section{Climate change mitigation and allergic disease prevention}

One major challenge for climate change mitigation is the resistance against countering global warming. In an interview with CNBC, the US Environmental Protection Agency Administrator and also a climate change sceptic, Mr Scott Pruitt, stated that he did not believe carbon dioxide is a cause of global warming. He also described the Paris Agreement, where representatives from 190 countries agreed to work towards lowering carbon dioxide emissions, as a 'bad deal. ${ }^{72}$ More than 20 non-profit groups supported him and contributed more than US\$88 million to spread climate science disinformation via think tanks and advocacy groups to support contrarian 'science' intended to create doubt about the prevailing science of anthropogenic climate change, mostly from fossil fuel interest groups, following the example of the Big Tobacco's efforts to derail anti-tobacco legislation.

Despite this, a large body of scientific evidence shows that fossil fuel burning is the main cause of climate change. The use of renewable energy such as solar, wind, ocean, biomass, geothermal resources for electricity and heat generation to replace conventional fossil fuel combustion is an important strategy. Reforestation, afforestation, and avoidance of desertification require multinational and well-coordinated efforts. For example, China is shifting from fossil fuel to renewable energy with related investments rising from US\$3 billion in 2005 to US\$127 billion in 2017, more than the US and EU combined. ${ }^{73}$ Another example is India's Forest Rights Act that aims to strike a balance between agriculture, urbanisation, and forest protection via legal reinforcement. This act protects the grassland and national parks from unauthorised agricultural activities and ensures livestock are fed in designated areas, and places a ban via legal measures on unauthorised deforestation. ${ }^{74}$ The intergovernmental panel on climate change established by the United Nations Environment Programme and the WMO is currently the international scientific collaborative network focusing on a multinational approach to climate change mitigation.

Efficient energy use is critical to reduce the energy consumption. New techniques in home insulation are available that can help reduce space heating and cooling requirements while maintaining a comfortable indoor temperature without additional energy consumption. Lighting using light-emitting diodes or compact fluorescent lights consume less than a quarter of the energy and are much longerlasting than traditional incandescent light bulbs. In addition, the use of skylights reduces the energy required to attain the same level of illumination and they are now more commonly incorporated in architectural designs. 
Low carbon living is a lifestyle that emits less carbon dioxide using the $4 \mathrm{Rs}$ of environmental protection principles: reduce, reuse, recycle, and replace. It is becoming an increasingly important refrain that is being heard more often. Below are some practical examples: concerning food selection, choose more vegetables and less meat, more organic and fresh foods rather than processed foods, local production rather than imported foods, purchase and prepare the amount of food according to actual need in order to avoid wastage or leftovers, or avoid accumulation of too much food that cannot be consumed before the expiry date; bring along reusable storage bags, and avoid restaurants that using disposable cutlery and crockery such as wooden chopsticks, plastic plates and plastic bowls; donate excessive food items to food banks before their expiry; use less oil during cooking (eg, avoid deep frying); send food waste and packaging for recycling as much as possible; concerning transportation, use more public transport more often than privately owned cars; choose less polluting transportation such as Mass Transit Railway, trams or light buses that use liquefied petroleum gas; walk or cycle if the destination is nearby, and is healthy and environmentally friendly; avoid leaving a car engine idling without switching it off; choose an airline involved in 'carbon neutral' programmes when travelling abroad; concerning energy efficiency: choose grade 1 electrical appliances under the government's Energy Efficiency Labelling Scheme; turn off computer screens, laptops and television completely rather than using the standby mode; use air conditioners only when the temperature is higher than $26^{\circ} \mathrm{C}$, and set the temperature to about $25.5^{\circ} \mathrm{C}$ if they are in use. ${ }^{75}$

Lifestyle and behavioural changes remain the most important strategies at an individual level. Educational and incentive programmes should be provided for public stakeholders for environmental protection. As the prevalence of allergic diseases is correlated with global warming, a better mitigation of important climatic changes will help to alleviate the progressive increasing trend of allergic disease development.

\section{Conclusion}

Global warming is caused by human activities. A paradigm shift should take place to enable everyone to live a healthy and environmentally friendly lifestyle. Allergy prevention and biodiversity preservation should not be practised at an individual level only, as it is a true global health emergency. Strategies must continue to be planned and coordinated at an international level. Measures to mitigate global warming, preserve biodiversity, and prevent allergic diseases are interdependent disciplines that will need to continue to be a major advocacy and research focus in the next century and beyond.

\section{Declaration}

As an editor of this journal, KL Hon was not involved in the peer review process of this article. All other authors have no conflicts of interest to disclose. All authors had full access to the data, contributed to the study, approved the final version for publication, and take responsibility for its accuracy and integrity.

\section{References}

1. World Health Organization. Climate change and health. Available from: http://www.who.int/mediacentre/ factsheets/fs266/en/. Accessed 27 Sep 2017.

2. Hansen J, Ruedy R, Glascoe J, and Sato M. GISS analysis of surface temperature change. J Geophys Res 1999;104:30997-1022.

3. Hansen J, Ruedy R, Sato M, et al. A closer look at United States and global surface temperature change. J Geophys Res 2001;106:23947-63.

4. Karl TR, Trenberth KE. Modern global climate change. Science 2003;302:1719-23.

5. Ramaswamy V, Schwarzkopf MD, Randel WJ, Santer BD, Soden BJ, Stenchikov GL. Anthropogenic and natural influences in the evolution of lower stratospheric cooling. Science 2006;311:1138-41.

6. Marcott SA, Shakun JD, Clark PU, Mix AC. A reconstruction of regional and global temperature for the past 11,300 years. Science 2013;339:1198-201.

7. Hausfather Z, Cowtan K, Clarke DC, Jacobs P, Richardson $\mathrm{M}$, Rohde R. Assessing recent warming using instrumentally homogeneous sea surface temperature records. Sci Adv 2017;3:e1601207.

8. Levitus S, Antonov JI, Boyer TP, Locarnini RA, Garcia HE, Mishonov AV. Global ocean heat content 1955-2008 in light of recently revealed instrumentation problems. Geophys Res Lett 2009;36:L07608.

9. Church JA, White NJ. A 20th century acceleration in global sea-level rise. Geophys Res Lett 2006;33:L01602.

10. Alley RB, Brigham-Grette J, Miller GH, et al. Past Climate Variability and Change in the Arctic and at High Latitudes. Washington: US Climate Change Science Program; 2009.

11. Kwok R, Rothrock DA. Decline in Arctic sea ice thickness from submarine and ICESat records: 1958-2008. Geophys Res Lett 2009;36:L15501.

12. Jacob T, Wahr J, Pfeffer WT, Swenson S. Recent contributions of glaciers and ice caps to sea level rise. Nature 2012;482:514-8.

13. Gardner AS, Moholdt G, Cogley JG, et al. A reconciled estimate of glacier contributions to sea level rise: 2003 to 2009. Science 2013;340:852-7.

14. Marshall S. Climate change. Glacier retreat crosses a line. Science 2014;345:872.

15. Marzeion B, Cogley JG, Richter K, Parkes D. Glaciers. Attribution of global glacier mass loss to anthropogenic and natural causes. Science 2014;345:919-21.

16. Zemp M, Frey H, Gärtner-Roer I, et al. Historically unprecedented global glacier decline in the early 21 st century. J Glaciology 2015;61:745-62.

17. Groisman PY, Karl TR, Knight RW. Observed impact of snow cover on the heat balance and the rise of continental 
spring temperatures. Science 1994;263:198-200.

18. Frei A, Robinson DA. Northern Hemisphere snow extent: regional variability 1972-1994. Int J Climatol 1999;19:153560.

19. Kunkel KE, Robinson DA, Champion S, Yin X, Estilow T, Frankson RM. Trends and extremes in Northern Hemisphere snow characteristics. Curr Clim Change Rep 2016;2:65-73.

20. Kunkel KE, Karl TR, Easterling DR, et al. Probable maximum precipitation and climate change. Geophys Res Lett 2013;40:1402-8.

21. Kunkel KE, Karl TR, Brooks H, et al. Monitoring and understanding trends in extreme storms: state of the knowledge. BAMS 2013;94:499-514.

22. Meier MF, Dyurgerov MB, Rick UK, et al. Glaciers dominate eustatic sea-level rise in the 21st century. Science 2007;317:1064-7.

23. Bamber J, Riva R. The sea level fingerprint of recent ice mass fluxes. The Cryosphere 2010;4:621-7.

24. Radić V, Bliss A, Beedlow AC, Hock R, Miles E, Cogley JG. Regional and global projections of twenty-first century glacier mass changes in response to climate scenarios from global climate models. Clim Dyn 2014;42:37-58.

25. Chan EY, Goggins WB, Kim JJ, Griffiths SM. A study of intracity variation of temperature-related mortality and socioeconomic status among the Chinese population in Hong Kong. J Epidemiol Community Health 2012;66:3227.

26. Hong Kong Observatory. Record-breaking high temperature [press release]. Available from: http://www. hko.gov.hk/press/SP/pre20150808.htm. Accessed 16 May 2018.

27. Hong Kong Observatory. Hong Kong in a warming world. Available from: http://www.hko.gov.hk/climate_change/ climate_change_e.pdf. Accessed 16 May 2018.

28. D’Amato G, Holgate ST, Pawankar R, et al. Meteorological conditions, climate change, new emerging factors, and asthma and related allergic disorders. A statement of the World Allergy Organization. World Allergy Organ J 2015;8:25.

29. Santer BD, Taylor KE, Wigley TM, et al. A search for human influences on the thermal structure of the atmosphere. Nature 1996;382:39-46.

30. Hegerl GC, von Storch H, Hasselmann K, Santer BD, Cubasch U, Jones PD. Detecting greenhouse-gas-induced climate change with an optimal fingerprint method. J Climate 1996;9:2281-306.

31. Santer BD, Wehner MF, Wigley TM, et al. Contributions of anthropogenic and natural forcing to recent tropopause height changes. Science 2003;301:479-83.

32. Pawankar R, Holgate ST, Canonica GW, Lockey RF, Blaiss MS, editors. WAO White Book on Allergy: Update 2013. Milwaukee [WI], US: World Allergy Organization; 2013.

33. Fifth Assessment Report of the Intergovernmental Panel on Climate Change. Climate Change 2013: The Physical Science Basis; Summary for Policymakers. Intergovernmental Panel on Climate Change; 2013.

34. Brunekreef B, Holgate ST. Air pollution and health. Lancet 2002;360:1233-42.

35. Ariano R, Canonica GW, Passalacqua G. Possible role of climate changes in variations in pollen seasons and allergic sensitizations during 27 years. Ann Allergy Asthma Immunol 2010;104:215-22.
36. Celenza A, Fothergill J, Kupek E, Shaw RJ. Thunderstorm associated asthma: a detailed analysis of environmental factors. BMJ 1996;312:604-7.

37. Meng Z, Lu B. Dust events as a risk factor for daily hospitalization for respiratory and cardiovascular diseases in Minqin, China. Atmos Environ 2007;41:7048-58.

38. Mendell MJ, Mirer AG, Cheung K, Tong M, Douwes J. Respiratory and allergic health effects of dampness, mold, and dampness-related agents: a review of the epidemiologic evidence. Environ Health Perspect 2011;119:748-56.

39. Banerjee S, Resch Y, Chen KW, et al. Der p 11 is a major allergen for house dust mite-allergic patients suffering from atopic dermatitis. J Invest Dermatol 2015;135:102-9.

40. Potter PC, Motala C, Fenemore B, et al. Sensitisation to three cockroach species in Southern Africa. Curr Allergy Clin Immunol 2005;18:62-6.

41. Hales S, Lewis S, Slater T, Crane J, Pearce N. Prevalence of adult asthma symptoms in relation to climate in New Zealand. Environ Health Perspect 1998;106:607-10.

42. de Marco R, Poli A, Ferrari M, et al. The impact of climate and traffic-related $\mathrm{NO} 2$ on the prevalence of asthma and allergic rhinitis in Italy. Clin Exp Allergy 2002;32:1405-12.

43. Asher MI, Stewart AW, Mallol J, et al. Which population level environmental factors are associated with asthma, rhinoconjunctivitis and eczema? Review of the ecological analyses of ISAAC Phase One. Respir Res 2010;11:8.

44. Venables KM, Allitt U, Collier CG, et al. Thunderstormrelated asthma - the epidemic of 24/25 June 1994. Clin Exp Allergy 1997;27:725-36.

45. Marks GB, Colquhoun JR, Girgis ST, et al. Thunderstorm outflows preceding epidemics of asthma during spring and summer. Thorax 2001;56:468-71.

46. Girgis ST, Marks GB, Downs SH, Kolbe A, Car GN, Paton $\mathrm{R}$. Thunderstorm-associated asthma in an inland town in south-eastern Australia: who is at risk? Eur Respir J 2000;16:3-8.

47. Losappio L, Heffler E, Contento F, Cannito C, Rolla G. Thunderstorm-related asthma epidemic owing to Olea Europaea pollen sensitisation. Allergy 2011;66:1510-1.

48. Woodhead M. Hospitals overwhelmed with patients after "thunderstorm asthma" hits Melbourne. BMJ 2016;355:16391.

49. Andrew E, Nehme Z, Bernard S, et al. Stormy weather: a retrospective analysis of demand for emergency medical services during epidemic thunderstorm asthma. BMJ 2017;359:j5636.

50. Lam HC, Li AM, Chan EY, Goggins WB 3rd. The shortterm association between asthma hospitalisations, ambient temperature, other meteorological factors and air pollutants in Hong Kong: a time-series study. Thorax 2016;71:1097-109.

51. Qiu H, Yu IT, Tse LA, Chan EY, Wong TW, Tian L. Greater temperature variation within a day associated with increased emergency hospital admissions for asthma. Sci Total Environ 2015;505:508-13.

52. Hong J, Zhong T, Li H, et al. Ambient air pollution, weather changes, and outpatient visits for allergic conjunctivitis: A retrospective registry study. Sci Rep 2016;6:23858.

53. Mimura $T$, Ichinose $T$, Yamagami $S$, et al. Airborne particulate matter (PM2.5) and the prevalence of allergic conjunctivitis in Japan. Sci Total Environ 2014;487:493-9.

54. Mimura T, Yamagami S, Fujishima H, et al. Sensitization to Asian dust and allergic rhinoconjunctivitis. Environ Res 
2014;132:220-5.

55. Chang CC, Lee IM, Tsai SS, Yang CY. Correlation of Asian dust storm events with daily clinic visits for allergic rhinitis in Taipei, Taiwan. J Toxicol Environ Health A 2006;69:22935.

56. World Health Organization. Health aspects of air pollution with particulate matter, ozone and nitrogen dioxide. 2003. Available from: http://www.euro.who.int/_data/assets/ pdf_file/0005/112199/E79097.pdf. Accessed 6 Feb 2018.

57. Bekö G, Callesen M, Weschler CJ, et al. Phthalate exposure through different pathways and allergic sensitization in preschool children with asthma, allergic rhinoconjunctivitis and atopic dermatitis. Environ Res 2015;137:432-9.

58 . Williams R. Climate change blamed for rise in hay fever Nature 2005;434:1059.

59. Weiland SK, Hüsing A, Strachan DP, Rzehak P, Pearce N; ISSAC Phase One Study Group. Climate and the prevalence of symptoms of asthma, allergic rhinitis, and atopic eczema in children. Occup Environ Med 2004;61:609-15.

60. Arbes SJ Jr, Gergen PJ, Elliott L, Zeldin DC. Prevalences of positive skin test responses to 10 common allergens in the US population: results from the third national health and nutrition examination survey. J Allergy Clin Immunol 2005;116:377-83.

61. Boulet LP, Turcotte H, Laprise C, et al. Comparative degree and type of sensitization to common indoor and outdoor allergens in subjects with allergic rhinitis and/or asthma. Clin Exp Allergy 1997;27:52-9.

62. Dice JP. Physical urticarial. Immunol Allergy Clin North Am 2004;24:225-46.

63. Haahtela T, Holgate S, Pawankar R, et al. The biodiversity hypothesis and allergic disease: world allergy organization position statement. World Allergy Organ J 2013;6:3.

64. Aukema JE, Pricope NG, Husak GJ, Lopez-Carr D. Biodiversity areas under threat: overlap of climate change and population pressures on the world's biodiversity priorities. PLoS One 2017;12:1.

65. Convention on Biological Diversity. Global Biodiversity Outlook 4: A Mid-term Assessment of Progress towards the
Implementation of the Strategic Plan for Biodiversity 20112020. Montréal, Canada: Secretariat of the Convention on Biological Diversity; 2014.

66. Robinson CL, Baumann LM, Romero K, et al. Effect of urbanisation on asthma, allergy and airways inflammation in a developing country setting. Thorax 2011;66:1051-7.

67. Huang YJ, Marsland BJ, Bunyavanich S, et al. The microbiome in allergic disease: current understanding and future opportunities-2017 PRACTALL document of the American Academy of Allergy, Asthma \& Immunology and the European Academy of Allergy and Clinical Immunology. J Allergy Clin Immunol 2017;139:1099-110.

68. Braun-Fahrländer C, Riedler J, Herz U, et al. Environmental exposure to endotoxin and its relation to asthma in schoolage children. N Engl J Med 2002;347:869-77.

69. Demain JG, Gessner BD, McLaughlin JB, Sikes DS, Foote JT. Increasing insect reactions in Alaska: is this related to changing climate? Allergy Asthma Proc 2009;30:238-43.

70. Bertelsmeier C, Luque GM, Courchamp F. Increase in quantity and quality of suitable areas for invasive species as climate changes. Conserv Biol 2013;27:1458-67.

71. Lobell DB, Schlenker W, Costa-Roberts J. Climate trends and global crop production since 1980. Science 2011;333:616-20.

72. DiChristopher T. EPA chief Scott Pruitt says carbon dioxide is not a primary contributor to global warming. CNBC Politics news. Available from: https://www.cnbc. com/2017/03/09/epa-chief-scott-pruitt.html. Accessed 30 Jan 2018.

73. Frankfurt School-UNEP Centre/BNEF. Global Trends in Renewable Energy Investment 2018. Frankfurt School of Finance \& Management gGmbH; 2018.

74. Boysen LR, Lucht W, Gerten D, Heck V, Lenton TM, Schellnhuber HJ. The limits to global-warming mitigation by terrestrial carbon removal. Earth's Future 2017;5:46374

75. Pimm SL, Jenkins CN, Abell R, et al. The biodiversity of species and their rates of extinction, distribution, and protection. Science 2014;344:1246752. 